\title{
PENENTUAN KESAMAAN RESERVOAR SISTEM PANAS BUMI KADIDIA DAN KADIDIA SELATAN KABUPATEN SIGI, PROVINSI SULAWESI TENGAH BERDASARKAN METODA GEOKIMIA
}

\section{DETERMINATION OF RESERVOIR SIMILARITY OF KADIDIA AND KADIDIA SELATAN GEOTHERMAL SYSTEMS BASED ON GEOCHEMICAL METHOD IN SIGI REGENCY, CENTRAL SULAWESI PROVINCE}

\author{
Andri Eko Ari Wibowo, Mochamad Nurhadi, Yuanno Rezky, \\ Dudi Hermawan, Dede lim Setiawan \\ Pusat Sumber Daya Geologi \\ Jalan Soekarno Hatta No.444, Bandung \\ Email: andri.bdg@gmail.com
}

\begin{abstract}
SARI
Pembentukan sistem panas bumi di daerah Kadidia dan Kadidia Selatan diperkirakan berhubungan dengan aktivitas tektonik yang masih aktif yaitu pada segmen sesar Palu Koro. Hal ini memungkinkan sistem panas buminya mempunyai manifestasi dan reservoar yang bertemperatur tinggi. Litologi daerah ini didominasi oleh batuan plutonik dengan jenis granit dengan bagian depresinya diisi oleh endapan permukaan.

Ditemukannya manifestasi air panas dan tanah panas bertemperatur mendidih di Kadidia Selatan mengindikasikan sistem ini mempunyai temperatur reservoar yang tinggi. Panas yang tinggi ini dipicu oleh aktivitas tektonik yang masih aktif yang memanaskan kembali batuan granit. Temperatur reservoar daerah Kadidia Selatan diperkirakan $240^{\circ} \mathrm{C}$ dengan pembentukan fluida panas bumi yang berasal dari pencampuran dengan fluida magmatis. Sedangkan daerah Kadidia yang memiliki temperatur yang lebih rendah, sistem panas bumi ini diperkirakan berhubungan dengan sirkulasi dalam dimana air meteorik terpanaskan oleh batuan panas yang kemudian muncul di permukaan sebagai air panas, dengan temperatur reservoar daerah Kadidia diperkirakan $130^{\circ} \mathrm{C}$ s.d $140^{\circ} \mathrm{C}$.

Sistem panas bumi Kadidia dan Kadidia Selatan diperkirakan mempunyai reservoar yang berbeda. Hal ini terlihat dari karakteristik geokimia fluida yang berbeda seperti komposisi unsur-unsur utama, unsur-unsur konservatif, daya hantar listrik, dan isotop. Litologi batuan yang berbeda serta adanya sesar yang membatasi kedua sistem ini juga menegaskan bahwa kedua daerah ini mempunyai reservoar yang berbeda. Namun untuk mengetahui apakah kedua daerah ini mempunyai sistem yang sama atau tidak, belum dapat diketahui karena membutuhkan kajian lebih lanjut.
\end{abstract}

Kata kunci : panas bumi, non-vulkanik, sesar aktif Palu Koro

\section{ABSTRACT}

Kadidia and Kadidia Selatan geothermal system are thought to be related to Palu Koro fault activity. This enables the geothermal system to have a high temperature of manifestations and reservoar. Lithology of this area is dominated by granitic type of plutonic rock, with the depresion area filled by surficial deposit.

Boiling springs and high temperature hot ground that are found in Kadidia Selatan indicate this system has high temperature of reservoar. This high heat was trigerred by tectonic activity that reheating the possible heat source. The reservoar temperature of this system is 


\section{MAKALAH ILMIAH}

about $240^{\circ} \mathrm{C}$ with the source of geothermal fluid came from mixing with magmatic fluid. Kadidia geothermal system, that has lower temperature, is estimated to be related to deep circulation system where meteoric water was heated by heated rock in the depth and reach to the surface as hot spring. The reservoar temperature of this system is about $130-140^{\circ} \mathrm{C}$.

Kadidia and Kadidia Selatan is estimated to have different reservoar. It is known from the differences of fluid characteristic such as chemical composition of major element, conservative element, conductivity, and isotopic ratio. The differences of rock lithology and the presence of fault system which separate the geothermal system are also confirming that these two areas have different reservoars. However, further studies are necessary to find out whether these areas have the same geothermal system.

Keyword : geothermal, non-volcanic, Palu Koro active fault

\section{PENDAHULUAN}

Sistem panas bumi di Indonesia dibagi menjadi sistem panas bumi vulkanik dan non-vulkanik. Di Indonesia sistem panas bumi non-vulkanik belum dimanfaatkan sebagai sumber energi listrik, salah satunya karena kurangnya pemahaman mengenai geosains sistem tersebut. Sistem panas bumi di Sulawesi, selain di Sulawesi bagian Utara, sebagian besar lokasi panas bumi berasosiasi dengan sistem non-vulkanik, diantaranya Kadidia. Secara administratif, daerah Kadidia berada wilayah Kabupaten Sigi, Provinsi Sulawesi Tengah (Gambar 1).

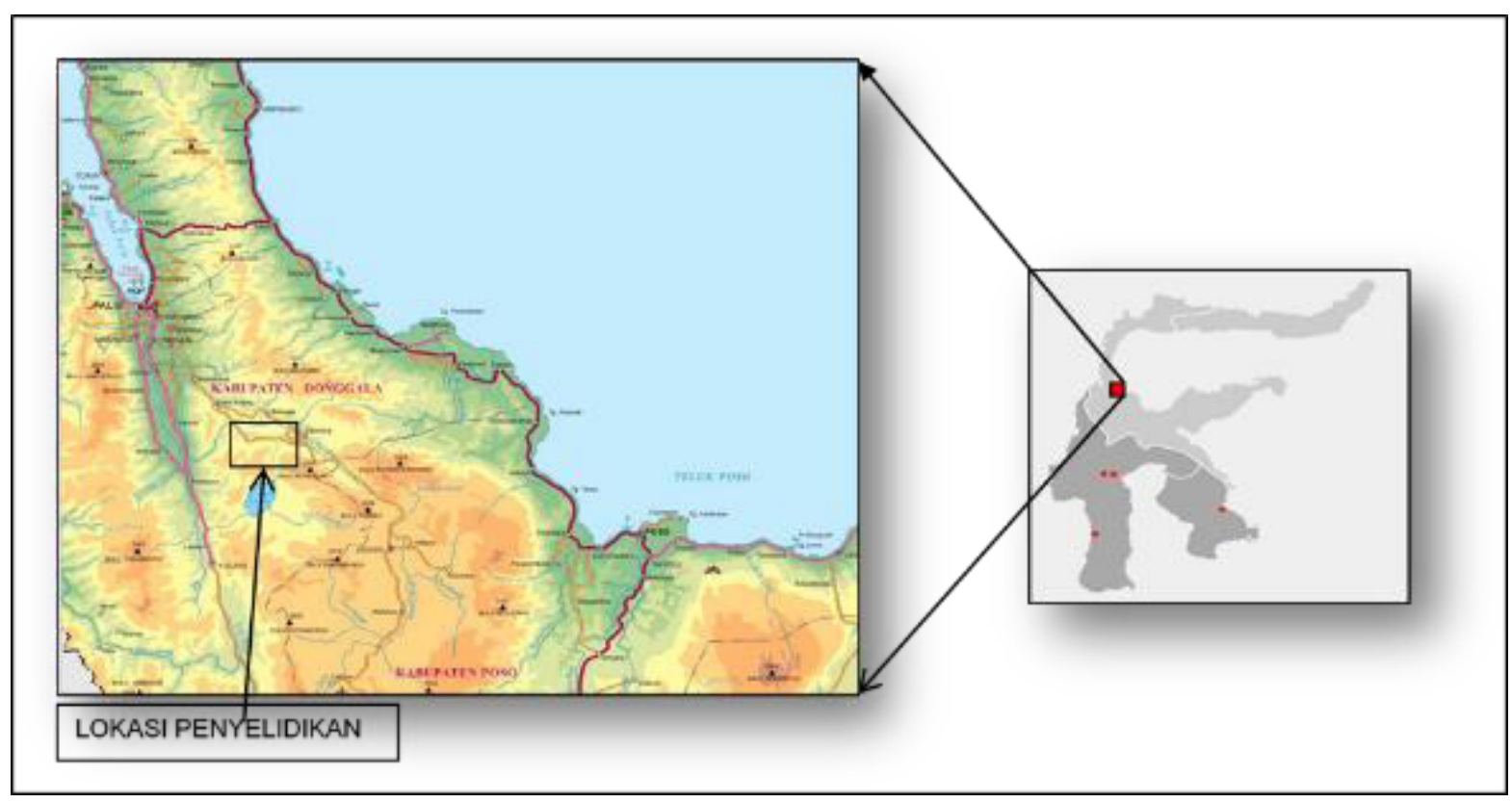

Gambar 1. Lokasi Daerah Penyelidikan

Daerah panas bumi Kadidia terletak pada tataan geologi Sulawesi bagian Tengah. Secara geologi, batuan di daerah Kadidia didominasi oleh batuan plutonik dengan jenis granit dan batuan metamorf. Pembentukan sistem panas bumi di daerah tersebut erat kaitannya dengan aktivitas tektonik yang masih aktif hingga saat ini yaitu segmen sesar aktif Palu Koro.

Pemunculan manifestasi panas bumi tersebar dari daerah tinggian Tongoa yang memanjang ke arah utara hingga ke 
daerah depresi Kadidia sepanjang sekitar $11 \mathrm{~km}$. Manifestasi panas bumi dipermukaan yang muncul di daerah depresi disebut sebagai kelompok
Kadidia, sedangkan yang di daerah tinggian Tongoa disebut kelompok Kadidia Selatan

(Gambar

2).

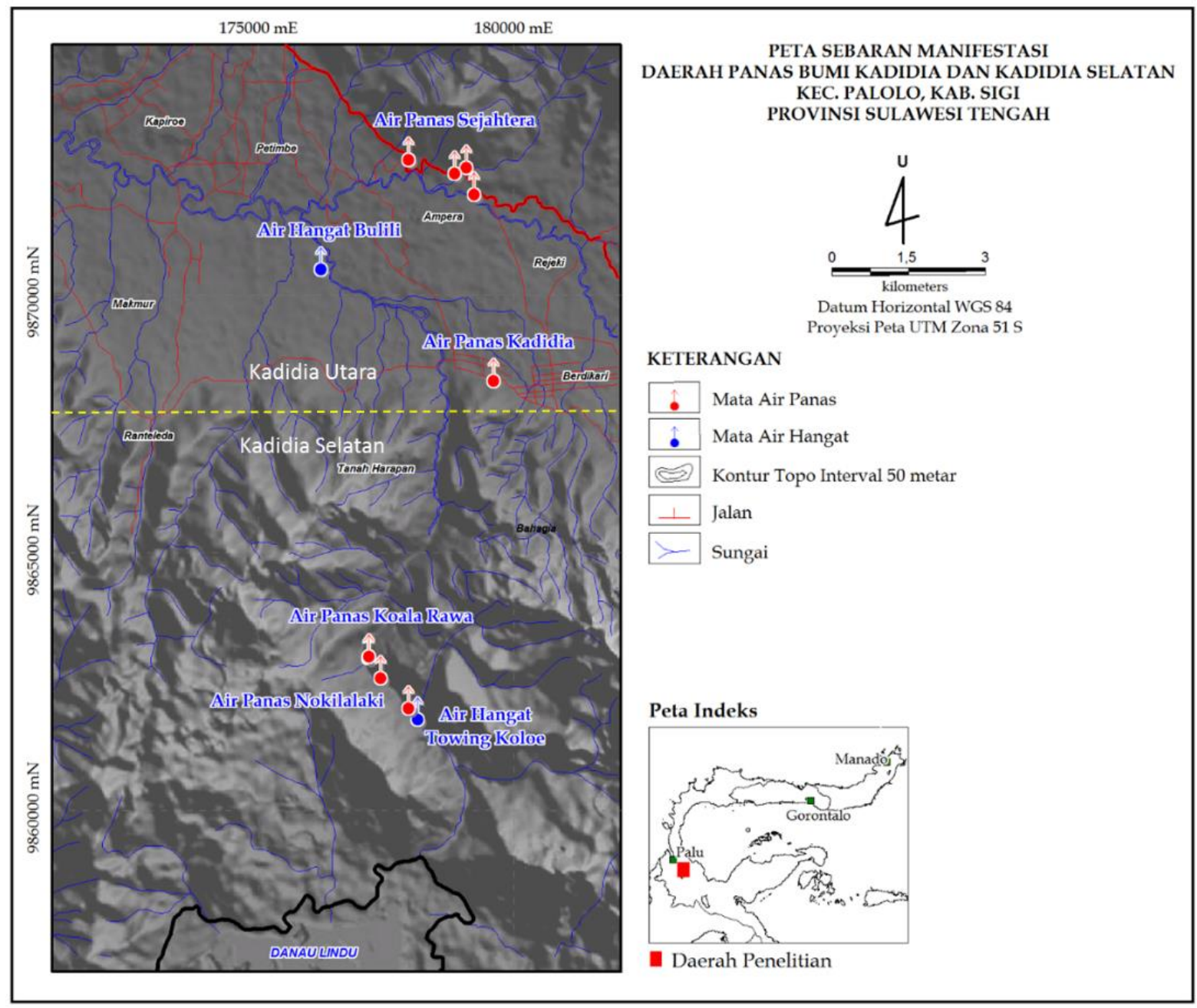

Gambar 2. Peta sebaran manifestasi daerah panas bumi Kadidia dan Kadidia Selatan

Manifestasi panas bumi di permukaan yang muncul di Kadidia berupa mata air panas $\left(51^{\circ} \mathrm{C}\right.$ s.d $\left.81^{\circ} \mathrm{C}\right)$ dan batuan alterasi. Air panas Kadidia mempunyai derajat keasaman $\mathrm{pH}$ netral sampai cenderung basa dan mempunyai daya hantar listrik (DHL) 500 - $700 \mu \mathrm{S} / \mathrm{cm}$. Sedangkan manifestasi di daerah Kadidia Selatan berupa mata air panas, tanah panas, dan batuan alterasi. Temperatur air panas berkisar $80,5^{\circ} \mathrm{C}$ s.d $98,8^{\circ} \mathrm{C}, \mathrm{pH}$ netral kearah basa, dan daya hantar listrik (DHL) 1.400 - $1.800 \mu \mathrm{S} / \mathrm{cm}$, dan tanah panas beruap dengan temperatur $100^{\circ} \mathrm{C}$.
Sumber fluida manifestasi yang muncul di daerah Kadidia dan Kadidia Selatan ini masih diperdebatkan apakah berasal dari sumber reservoar yang sama atau tidak. Melalui pemodelan berdasarkan data geologi dan geokimia diharapkan dapat menjawab perdebatan tersebut.

\section{GEOLOGI DAERAH PENELITIAN}

Batuan tertua yang tersingkap di daerah penyelidikan berupa batuan malihan derajat rendah dari jenis granit yang secara regional termasuk ke dalam Granit 


\section{MAKALAH ILMIAH}

Kambuno berumur Pliosen. Kegiatan magmatisme terus berlangsung hingga terbentuknya batuan plutonik terakhir berkomposisi granitik-dasitik yang juga dijumpai di daerah penyelidikan. termuda di daerah penyelidikan (Gambar 3). Satuan plutonik yang paling muda berkomposisi granitik-dasitik ini diperkirakan berumur Plio-plistosen, menembus satuan batuan yang lebih tua, dan diperkirakan sebagai satuan yang berasosiasi dengan batuan di bawah permukaan yang masih menyimpan panas.

Kegiatan tektonik berlangsung seiring dengan kegiatan magmatisme muda baik berupa pengangkatan maupun regangan. Proses pengangkatan ditandai dengan tersingkapnya batuan-batuan plutonik ke permukaan, sedangkan proses regangan ditandai dengan terbentuknya pull-apart basin di bagian tengah daerah penyelidikan. Cekungan yang terbentuk akibat depresi ini diisi oleh materialmaterial sedimen hasil rombakan batuan yang lebih tua, diantaranya adalah endapan danau, koluvium, kipas aluvium, dan endapan aluvium. Endapan aluvial
Setidaknya diamati delapan litologi batuan plutonik yang berlangsung dari terbentuknya metagranit, ditandai dengan granit $7(\mathrm{Qg} 7)$ dan granit $8(\mathrm{Qg} 8)$ yang diperkirakan merupakan batuan plutonik merupakan satuan batuan termuda di daerah penyelidikan, proses pembentukannya masih terus berlangsung hingga sekarang.

Tektonisme yang masih aktif hingga saat ini adalah pergerakan sesar aktif Palu Koro yang salah satu segmennya mengarah ke daerah penelitian dengan arah barat baratlaut - timur tenggara (NWW-SEE). Aktifitas tektonik ini yang diperkirakan mengontrol pembentukan sistem panas bumi di daerah Kadidia dan Kadidia Selatan. Morfologi pedataran di Kadidia terbentuk oleh suatu perkembangan depresi yang dikontrol oleh mekanisme pull-apart dari sesar mendatar berarah barat baratlaut - timur tenggara (NWW-SEE) dan sesar-sesar normal yang terbentuk di dalamnya. Depresi ini membentuk suatu cekungan dimana di dalamnya terakumulasi endapan permukaan.

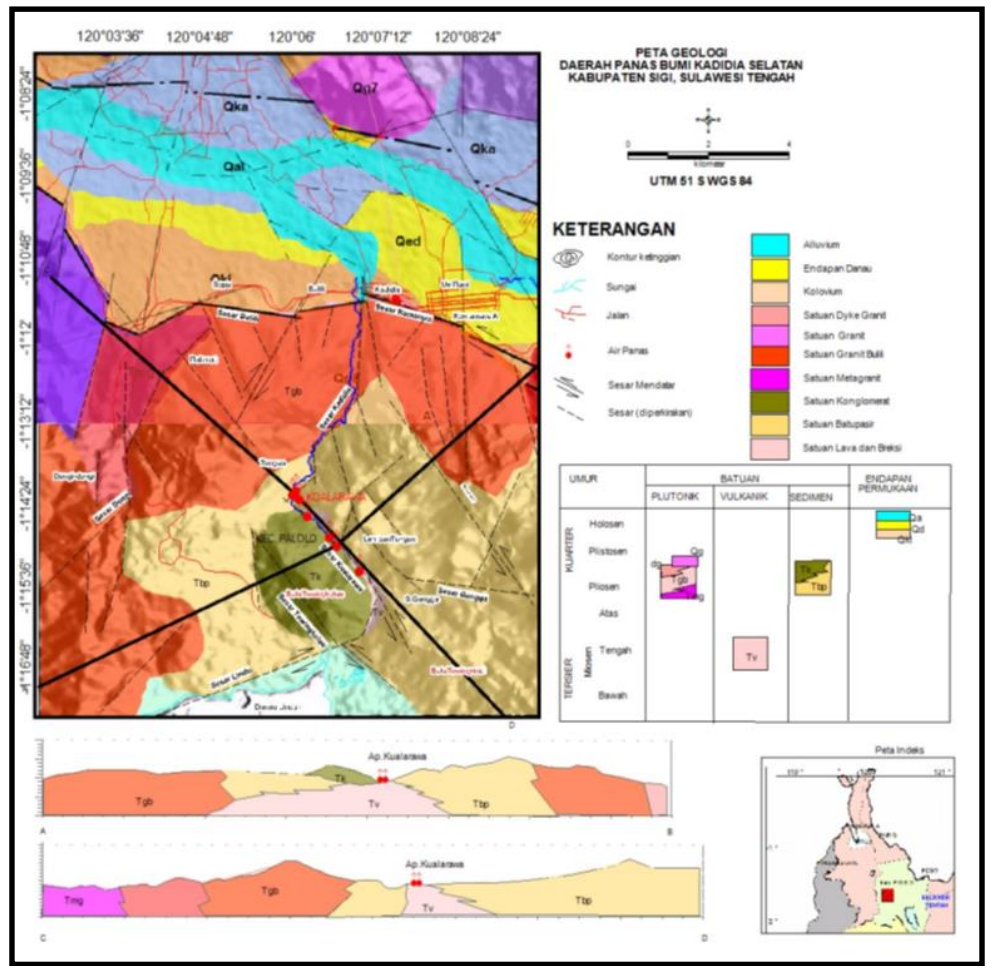

Gambar 3. Peta geologi daerah panas bumi Kadidia dan Kadidia Selatan 


\section{METODOLOGI}

Metodologi yang digunakan dalam penelitian ini berupa pengamatan di lapangan, pengambilan conto, analisis laboratorium dan interpretasi data. Pengamatan yang dilakukan di lapangan meliputi pengamatan sebaran batuan ubahan dan karakteristik fisik manifestasi panas bumi seperti temperatur, $\mathrm{pH}$, debit air dan daya hantar listrik. Pengamatan geologi meliputi pengamatan litologi dan indikasi struktur-struktur geologi yang muncul. Pengambilan conto geokimia berupa pengambilan conto air dan batuan ubahan, untuk selanjutnya dilakukan analisis mineral ubahan dan geokimia air seperti anion, kation dan isotop di laboratorium. Pengambilan conto gas juga dilakukan pada hembusan-hembusan uap panas yang terdapat pada sekitar tanah panas di area manifestasi Koala Rawa.

Metode analisis yang digunakn terhadap 15 unsur-unsur terlarut meliputi anion utama $\mathrm{Cl}^{-}, \mathrm{SO}_{4}{ }^{2-}, \mathrm{HCO}_{3}{ }^{-}$, kation seperti $\mathrm{Ca}^{2+}, \mathrm{Na}^{+}, \mathrm{K}^{+}, \mathrm{Mg}^{2+}, \mathrm{Li}^{+}$dan beberapa senyawa dan unsur netral seperti $\mathrm{SiO}_{2}$, $\mathrm{NH}_{3}, \mathrm{~F}, \mathrm{~B}$, menggunakan ion kromatografi, Atomic Absorption Spectrophotometer (AAS) dan spektrometri. Untuk mengetahui kandungan isotop stabil Deuterium dan Oksigen-18 digunakan Mass Spectrometer (MS). Mineralogi penyusun batuan ubahan dideskripsi dengan menggunakan analisis petrografi yang didukung dengan analisis Spektra Mineral dengan menggunakan alat Portable Infrared Mineral Analyzer (PIMA). Metode analisis gas menggunakan kromatografi gas (GC) untuk mengetahui komposisi $\mathrm{He}, \mathrm{H}_{2}, \mathrm{O}_{2}, \mathrm{Ar}, \mathrm{N}_{2}, \mathrm{CH}_{4}, \mathrm{CO}$, $\mathrm{CO}_{2}, \mathrm{H}_{2} \mathrm{~S}, \mathrm{HCl}$, dan $\mathrm{NH}_{3}$. Data hasil analisis laboratorium kemudian diinterpretasi sehingga karakateristik fluida yang terdapat di daerah penelitian dapat diketahui yang selanjutnya digunakan untuk pembuatan model geokimia.

\section{HASIL DAN PEMBAHASAN}

\section{Manifestasi Panas Bumi Di Permukaan}

Kenampakan gejala panas bumi di daerah penelitian berupa mata air panas, tanah panas, dan batuan alterasi yang muncul di beberapa lokasi (lihat Gambar 2). Karakteristik fisik dari manifestasi air panas dan air hangat ditampilkan pada tabel 1. Pada tabel 1 terlihat bahwa temperatur manifestasi dan nilai $\mathrm{DHL}$ di Kadidia Selatan lebih tinggi dibandingkan di Kadidia. Di Kadidia Selatan juga ditemukan tanah panas Koala Rawa yang berada di dalam kompleks manifestasi Koala Rawa dengan suhu tanah panas berkisar antara $50-100^{\circ} \mathrm{C}$ dan luas sekitar $100 \times 100 \mathrm{~m}$.

Batuan ubahan intensif ditemukan di Kadidia Selatan yang terbentuk di sepanjang sungai Koala Rawa dengan warna fisik kehijauan dan putih hingga kekuningan. Di sekitar Koala Rawa ubahan mencapai $1 \mathrm{~km}^{2}$ dengan komposisi mineral seperti montmorilonit, paragonit, epidot, alunit, ilit, kaolinit, halosit. Mineral epidot, ilit dan kaolinit menunjukan mineral yang terbentuk pada temperatur tinggi, sedangkan montmorilonit pada temperatur rendah dengan $\mathrm{pH}$ netral. Terdapat pula sinter karbonat dan sinter silika di sekitar manifestasi Kadidia Selatan. 


\section{MAKALAH ILMIAH}

Tabel 1. Manifestasi panas bumi daerah Kadidia dan Kadidia Selatan

\begin{tabular}{|c|c|c|c|c|c|c|}
\hline NO & MANIFESTASI & LOKASI & $\begin{array}{c}\text { TEMPERATUR } \\
\left({ }^{\circ} \mathrm{C}\right)\end{array}$ & $\mathrm{pH}$ & $\begin{array}{c}\mathrm{DHL} \\
(\mu \mathrm{S} / \mathrm{cm})\end{array}$ & $\begin{array}{l}\text { DEBIT } \\
\text { (It/dtk) }\end{array}$ \\
\hline 1 & $\begin{array}{l}\text { Kelompok air } \\
\text { panas Nokilalaki }\end{array}$ & \multirow{4}{*}{$\begin{array}{l}\text { Kadidia } \\
\text { Selatan }\end{array}$} & $80,5-96,4$ & $7,9-8,3$ & $1.450-1.701$ & $\begin{array}{l}0,1- \\
0,5\end{array}$ \\
\hline 2 & $\begin{array}{l}\text { Kelompok air } \\
\text { panas Koala } \\
\text { Rawa }\end{array}$ & & $96,6-98,8$ & $7,9-9,4$ & $1.803-1.844$ & $4-10$ \\
\hline 3 & $\begin{array}{l}\text { Air hangat } \\
\text { Towing Koloe }\end{array}$ & & 40,2 & 7,1 & 144 & 0,4 \\
\hline 4 & $\begin{array}{l}\text { Tanah Panas } \\
\text { Koala Rawa }\end{array}$ & & $50-100$ & - & - & - \\
\hline 5 & $\begin{array}{l}\text { Air panas } \\
\text { Kadidia }\end{array}$ & \multirow{3}{*}{ Kadidia } & 81,6 & 8,3 & 529 & 2 \\
\hline 6 & $\begin{array}{l}\text { Kelompok air } \\
\text { panas Sejahtera }\end{array}$ & & $51-62,8$ & $6,9-8,4$ & $500-700$ & 0,6 \\
\hline 7 & Air hangat Bulili & & 40,4 & 6,82 & 300 & 0,1 \\
\hline
\end{tabular}

\section{Hasil Analisis Laboratorium}

Enam conto air panas diperoleh di daerah Kadida yang meliputi air panas Sejahtera 1, 2, 3, dan 4, air panas Bulili, serta air panas Kadidia, sedangkan lima conto air panas yang lain diperoleh dari daerah
Kadidia selatan yaitu di lokasi air panas Koala Rawa 1 dan 2, air panas Nokilalaki 1 dan 2, serta air panas Towing Koloe. Hasil analisis kimia air yang terdapat di daerah penelitian ditampilkan dalam tabel 2.

Tabel 2. Hasil analisis kimia air panas daerah Kadidia dan Kadidia Selatan

\begin{tabular}{|c|c|c|c|c|c|c|c|c|c|c|c|c|}
\hline \multirow{2}{*}{\multicolumn{2}{|c|}{ PARAMETER }} & \multicolumn{6}{|c|}{ KADIDIA } & \multicolumn{5}{|c|}{ KADIDIA SELATAN } \\
\hline & & \multirow{2}{*}{\begin{tabular}{|c|}
$\begin{array}{c}\text { AP } \\
\text { Sejahtera 1 }\end{array}$ \\
APS-1 \\
\end{tabular}} & \multirow{2}{*}{$\begin{array}{c}\begin{array}{c}\text { AP } \\
\text { Sejahtera 2 }\end{array} \\
\text { APS-2 } \\
\end{array}$} & \multirow{2}{*}{\begin{tabular}{|c}
$\begin{array}{c}\text { AP } \\
\text { Sejahtera 3 }\end{array}$ \\
APS-3
\end{tabular}} & \multirow{2}{*}{$\begin{array}{c}\text { AP } \\
\text { Sejahtera 4 }\end{array}$} & \multirow{2}{*}{$\begin{array}{c}\text { AP } \\
\text { Bulili }\end{array}$} & \multirow{2}{*}{$\begin{array}{c}\begin{array}{c}\text { AP } \\
\text { Kadidia }\end{array} \\
\text { APK }\end{array}$} & \multirow{2}{*}{\begin{tabular}{|c} 
AP \\
Nokilalaki 1 \\
APNKL-1 \\
\end{tabular}} & \multirow{2}{*}{\begin{tabular}{|c|}
$\begin{array}{c}\text { AP } \\
\text { Nokilalaki 2 }\end{array}$ \\
APNKL-2 \\
\end{tabular}} & \multirow{2}{*}{$\begin{array}{c}\text { AP Koala } \\
\text { Rawa 1 } \\
\text { APKRW-1 }\end{array}$} & \multirow{2}{*}{$\begin{array}{c}\begin{array}{c}\text { AP Koala } \\
\text { Rawa 2 }\end{array} \\
\text { APKRW-2 }\end{array}$} & \multirow{2}{*}{$\begin{array}{c}\begin{array}{c}\text { AP Towing } \\
\text { Koloe }\end{array} \\
\text { APTWK } \\
\end{array}$} \\
\hline & & & & & & & & & & & & \\
\hline $\mathrm{pH}$ & & 6,97 & 8,41 & 7,83 & 7,75 & 6,82 & 8,32 & 8,32 & 7,90 & 9,41 & 7,91 & 7,10 \\
\hline DHL & $(\mu \mathrm{S} / \mathrm{cm})$ & 700 & 595 & 687 & 499 & 300 & 974 & 1727 & 1449 & 1815 & 1847 & 141 \\
\hline $\mathrm{SiO}_{2}$ &,$(\mathrm{mg} / \mathrm{L})$ & 54,94 & 58,34 & 57,85 & 42,39 & 42,81 & 65,37 & 296,40 & 195,84 & 270,83 & 275,51 & 47,82 \\
\hline B &,$(\mathrm{mg} / \mathrm{L})$ & 0,32 & 0,25 & 0,32 & 0,18 & 0,22 & 0,47 & 4,04 & 3,29 & 3,72 & 3,85 & 0,02 \\
\hline $\mathbf{A l}^{3+}$ &,$(\mathrm{mg} / \mathrm{L})$ & 0,01 & 0,08 & 0,01 & 1,05 & 0,00 & 0,08 & 0,03 & 0,01 & 0,02 & 0,06 & 0,01 \\
\hline $\mathrm{Fe}^{3+}$ &,$(\mathrm{mg} / \mathrm{L})$ & 0,07 & 0,05 & 0,06 & 0,93 & 0,07 & 0,14 & 0,01 & 0,01 & 0,01 & 0,06 & 0,01 \\
\hline $\mathrm{Ca}^{2+}$ &,$(\mathrm{mg} / \mathrm{L})$ & 7,86 & 0,31 & 5,83 & 1,83 & 9,49 & 2,19 & 12,30 & 20,30 & 8,60 & 15,00 & 10,05 \\
\hline $\mathrm{Mg}^{2+}$ &.$(\mathrm{mg} / \mathrm{L})$ & 1,78 & 0,12 & 0,59 & 0,77 & 1,91 & 0,1 & 0,01 & 6,01 & 0,90 & 1,50 & 4,24 \\
\hline $\mathrm{Na}^{+}$ &,$(\mathrm{mg} / \mathrm{L})$ & 95,12 & 87,13 & 112,80 & 64,24 & 54,52 & 128,3 & 343,50 & 294,80 & 379,60 & 372,40 & 15,96 \\
\hline $\mathbf{K}^{+}$ &,$(\mathrm{mg} / \mathrm{L})$ & 2,57 & 2,12 & 2,30 & 2,78 & 2,59 & 2,8 & 37,00 & 44,90 & 30,77 & 33,21 & 2,30 \\
\hline $\mathbf{L i}^{+}$ &,$(\mathrm{mg} / \mathrm{L})$ & 0,01 & 0,03 & 0,01 & 0,01 & 0,03 & 0,10 & 1,18 & 0,86 & 1,19 & 1,21 & 0,00 \\
\hline $\mathbf{A s}^{3+}$ &,$(\mathrm{mg} / \mathrm{L})$ & 0,50 & 0,00 & 0,00 & 0,00 & 0,00 & 0,00 & 1,00 & 0,01 & 1,00 & 1,00 & 0,01 \\
\hline $\mathrm{NH}_{4}{ }^{+}$ &.$(\mathrm{mg} / \mathrm{L})$ & 1,86 & 0,25 & 1,47 & 0,84 & 0,21 & 0,32 & 0,87 & 0,81 & 0,52 & 0,42 & 0,10 \\
\hline F &,$(\mathrm{mg} / \mathrm{L})$ & 2,36 & 4,20 & 3,50 & 0,86 & 0,99 & 2,69 & 3,81 & 2,09 & 3,78 & 3,88 & 0,05 \\
\hline $\mathrm{Cl}^{-}$ &,$(\mathrm{mg} / \mathrm{L})$ & 82,45 & 59,53 & 99,53 & 6,00 & 14,00 & 102,45 & 347,13 & 302,89 & 410,59 & 391,32 & 0,36 \\
\hline $\mathrm{SO}_{4}{ }_{4}^{2-}$ &,$(\mathrm{mg} / \mathrm{L})$ & 6,00 & 27,04 & 18,11 & 12,00 & 6,00 & 40,44 & 41,37 & 26,61 & 23,72 & 37,62 & 11,44 \\
\hline $\mathrm{HCO3}$ &,$(\mathrm{mg} / \mathrm{L})$ & 150,00 & 82,68 & 118,65 & 160,85 & 149,43 & 112,86 & 315,64 & 382,87 & 360,75 & 372,31 & 77,34 \\
\hline $\mathrm{CO}_{3}{ }^{=}$ &,$(\mathrm{mg} / \mathrm{L})$ & 0,00 & 0,00 & 0,00 & 0,00 & 0,00 & 0,00 & 0,00 & 0,00 & 0,00 & 0,00 & 0,00 \\
\hline & cat & 4,87 & 3,90 & 5,39 & 3,23 & 3,09 & 5,82 & 16,77 & 15,65 & 18,05 & 18,17 & 1,61 \\
\hline me & an. & 5,03 & 3,82 & 5, & 3,10 & 3,02 & 5,72 & 16,03 & 15,48 & 18,19 & 18,13 & 1,52 \\
\hline & IB & $-1,63$ & 1,05 & 0,74 & 2,12 & 1,10 & 0,83 & 2,25 & 0,54 & $-0,39$ & 0,11 & 2,95 \\
\hline
\end{tabular}


Sedangkan conto gas hanya didapatkan pada manifestasi Kadidia Selatan yang ditampilkan dalam tabel3.

Tabel 3. Hasil analisis kimia gas daerah panas bumi Kadidia Selatan

\begin{tabular}{|c|c|c|c|}
\hline \multicolumn{2}{|c|}{$\begin{array}{l}\text { KODE } \\
\text { CONTO }\end{array}$} & \multirow{2}{*}{$\begin{array}{c}\text { PB -5 } \\
2014 \\
\text { Dry base } \\
\mathrm{tt}\end{array}$} & \multirow{2}{*}{$\begin{array}{c}\text { PB -7 } \\
2014 \\
\text { Dry } \\
\text { base } \\
\mathrm{Tt}\end{array}$} \\
\hline $\mathrm{He}$ & $\% \mathrm{~mol}$ & & \\
\hline $\mathrm{H}_{2}$ & $\% \mathrm{~mol}$ & $\mathrm{tt}$ & $\mathrm{Tt}$ \\
\hline $\mathrm{O}_{2}$ & $\% \mathrm{~mol}$ & 20.0396 & 0.2516 \\
\hline $\mathrm{Ar}$ & $\% \mathrm{~mol}$ & 1.0353 & 0.8955 \\
\hline $\mathbf{N}_{2}$ & $\% \mathrm{~mol}$ & 75.7462 & 95.1403 \\
\hline $\mathrm{CH}_{4}$ & $\% \mathrm{~mol}$ & $\mathrm{tt}$ & $\mathrm{Tt}$ \\
\hline $\mathrm{CO}$ & $\% \mathrm{~mol}$ & $\mathrm{tt}$ & $\mathrm{Tt}$ \\
\hline $\mathrm{CO}_{2}$ & $\% \mathrm{~mol}$ & 2.6528 & 3.4979 \\
\hline $\mathrm{H}_{2} \mathrm{~S}$ & $\% \mathrm{~mol}$ & 0.0000 & 0.0000 \\
\hline $\mathrm{HCl}$ & $\% \mathrm{~mol}$ & 0.5239 & 0.2147 \\
\hline $\mathbf{N H}_{3}$ & $\% \mathrm{~mol}$ & 0.0022 & $\mathrm{Tt}$ \\
\hline
\end{tabular}

Ket : $\mathrm{tt}=$ tidak terdeteksi

\section{Karakteristik Fluida Panas Bumi}

Hasil analisis kimia pada Tabel 2 menunjukkan bahwa air panas dan air dingin di daerah penelitian mempunyai kesetimbangan ion (ion balance) kurang dari 5\%. Untuk mengetahui karakteristik dan tipe air panas berdasarkan data yang diperoleh pada Tabel 1, dilakukan plotting komposisi kimia dari mata air panas pada diagram segitiga $\mathrm{Cl}-\mathrm{SO}_{4}-\mathrm{HCO}_{3}, \mathrm{Na}-\mathrm{K}-\mathrm{Mg}$ dan Cl-Li-B yang mengacu pada Giggenbach (1988).

Berdasarkan diagram segitiga $\mathrm{Cl}-\mathrm{SO}_{4}{ }^{-}$ $\mathrm{HCO}_{3}$ (gambar 4), fluida panas bumi di sistem Kadidia dan Kadidia Selatan didominasi oleh air klorida dan air bikarbonat. Air klorida umumnya merupakan air panas bertemperatur tinggi seperti air panas Koala Rawa, Nokilalaki, Kadidia, dan Sejahtera 2 dan Sejahtera 3. Air panas Koala Rawa dan Nokilalaki di daerah Kadidia Selatan yang bertemperatur mendidih, berada pada zona mature water, yang mengindikasikan bahwa air panas tersebut berasal langsung dari reservoar. Hal ini juga ditunjukkan pada diagram segitiga Na-KMg (gambar 5) yang berada pada zona partial equilibrium, yang mencerminkan fluida reservoar dengan perkiraan temperatur fluida $200^{\circ} \mathrm{C}$ s.d $250^{\circ} \mathrm{C}$.

Demikian juga air panas Kadidia, Sejahtera 2 dan Sejahtera 3 berada di partial equilibrium namun diperkiraan berasal dari reservoar dengan temperatur lebih rendah yaitu $100^{\circ} \mathrm{C}$ s.d $140^{\circ} \mathrm{C}$. Air panas lainnya berada di zona immature water yang menunjukkan adanya pencampuran air permukaan dengan fluida reservoar.

Untuk mengetahui kesamaan reservoar (common source reservoir) berdasarkan fluida air panas dari daerah Kadidia dan Kadidia Selatan, dapat diketahui dengan menggunakan diagram segitiga CL-Li-B (Nicholson, 1993) (gambar 6). 


\section{MAKALAH ILMIAH}

Berdasarkan diagram segitiga tersebut, terlihat bahwa terdapat dua kelompok (cluster) air panas dengan karakteristik yang berbeda yang menunjukkan air panas Kadidia dan Kadidia Selatan berasal dari reservoar yang berbeda.
Namun untuk mengetahui apakah kedua daerah tersebut mempunyai sistem panas bumi yang sama atau tidak, belum dapat diketahui karena memerlukan penelitian lebih lanjut.

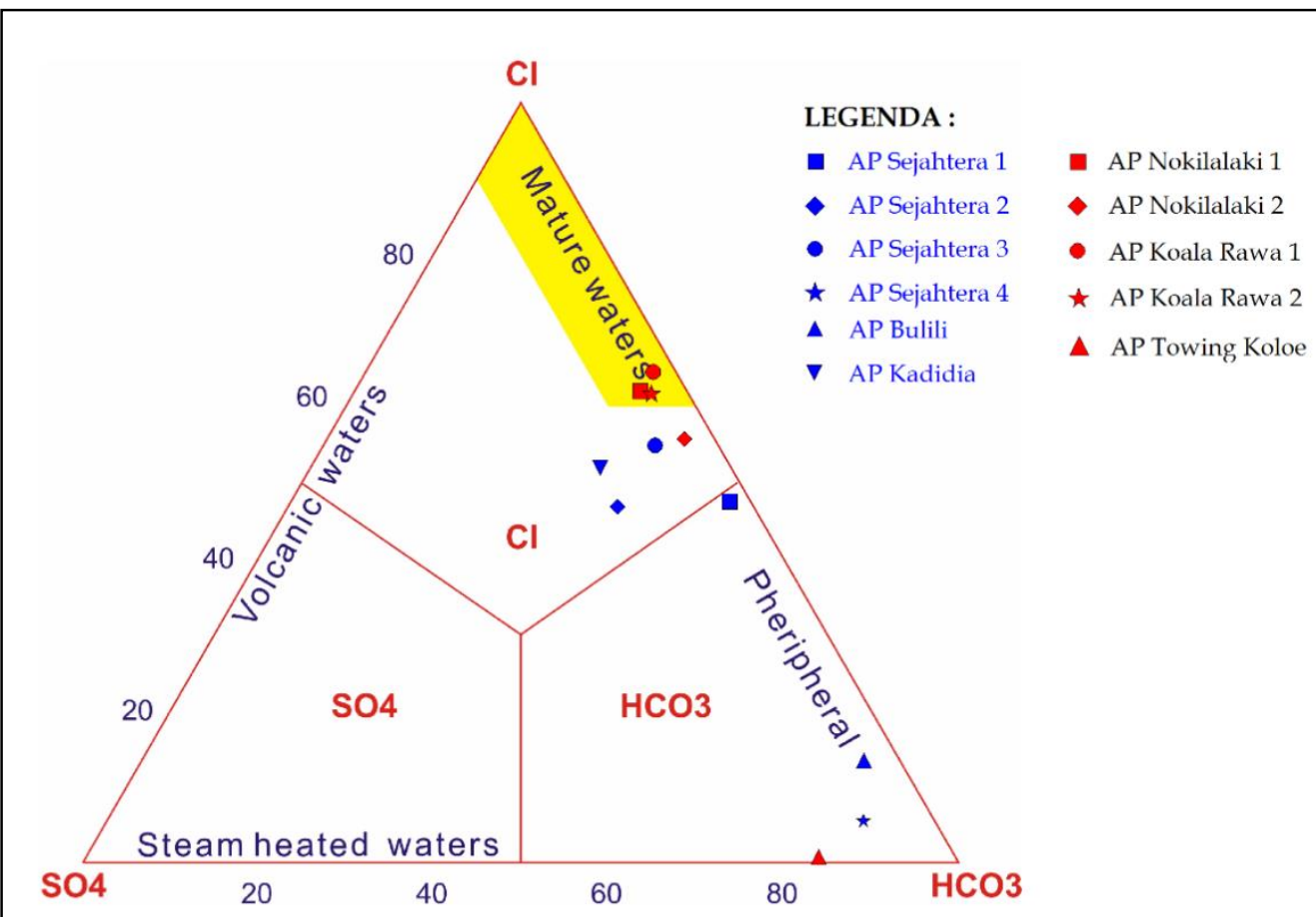

Gambar 4. Diagram segitiga $\mathrm{Cl}-\mathrm{SO}_{4}-\mathrm{HCO}_{3}$

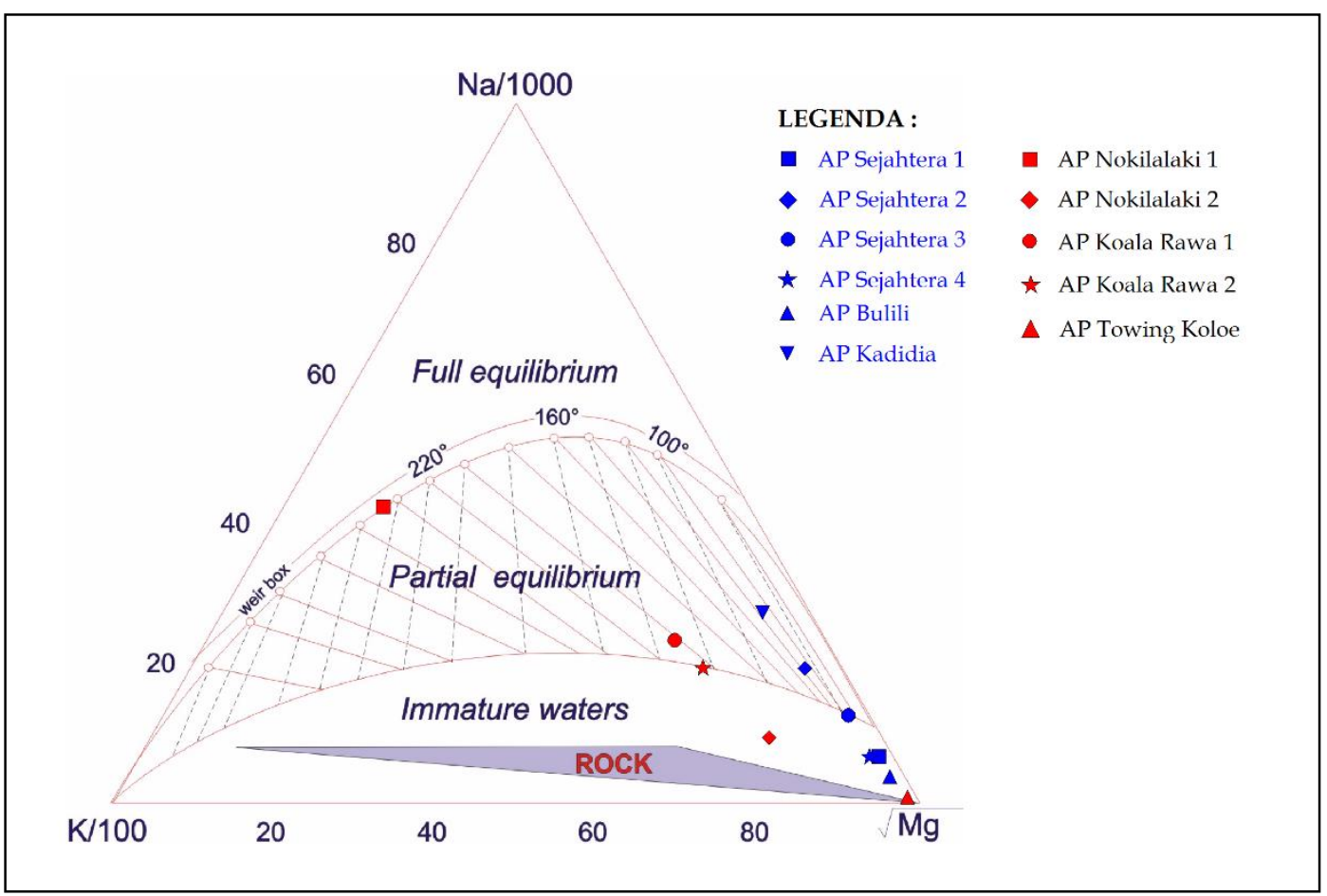




\section{MAKALAH ILMIAH}

Gambar 5. Diagram segitiga Na-K-Mg

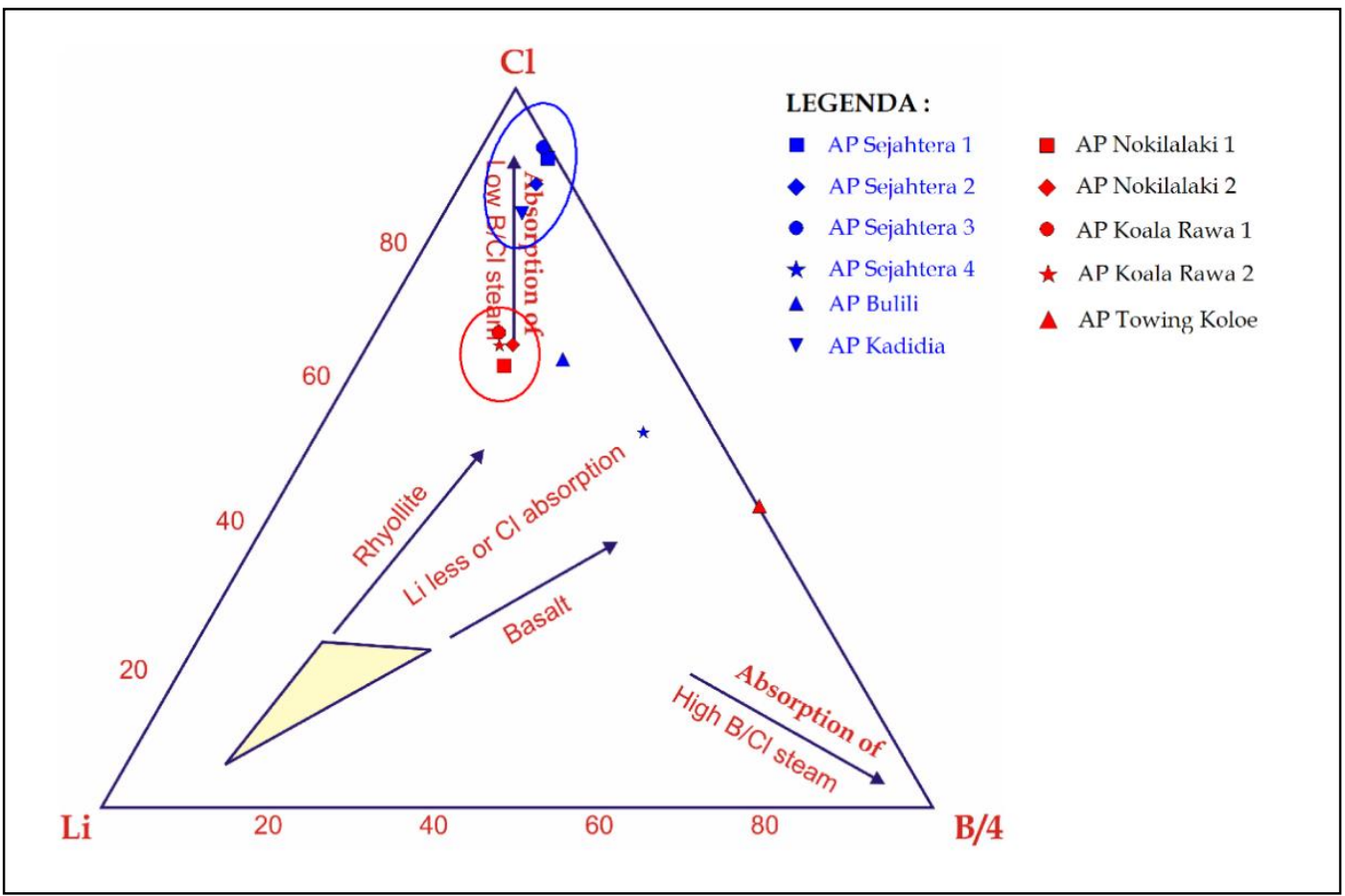

Gambar 6. Diagram segitiga Cl-Li-B

Berdasarkan data hasil analisis isotop ${ }^{18} \mathrm{O}$ dan Deuterium pada sampel air panas daerah Kadidia Selatan, yaitu Koala Rawa dan Nokilalaki yang mempunyai temperatur permukaan tinggi, cenderung menjauhi garis air meteorik (Meteoric Water Line) (gambar 7). Hal ini mengindikasikan telah terjadinya pengkayaan ${ }^{18} \mathrm{O}$ akibat adanya interaksi fluida panas dengan batuan di kedalaman atau kemungkinan pengenceran oleh air meteorik sangat kecil. Pada gambar 8 terlihat asal-usul pembentukan fluida panas bumi daerah Kadidia Selatan, yaitu terjadi mixing/pencampuran dengan fluida magmatik dengan perkiraan persentase komposisi fluida magmatik sebesar $\pm 10-20$ $\%$.

Untuk air panas lainnya di daerah Kadidia, hasil plotting terletak mendekati garis air meteorik. Hal ini mengindikasikan bahwa air panas tersebut dipengaruhi oleh air permukaan. Sebagai perbandingan dilakukan pula pengukuran isotop untuk air dingin di daerah Kadidia Selatan yang diambil dari mata air pegunungan dimana hasil plotting air dingin berada mendekati garis meteorik. 


\section{MAKALAH ILMIAH}

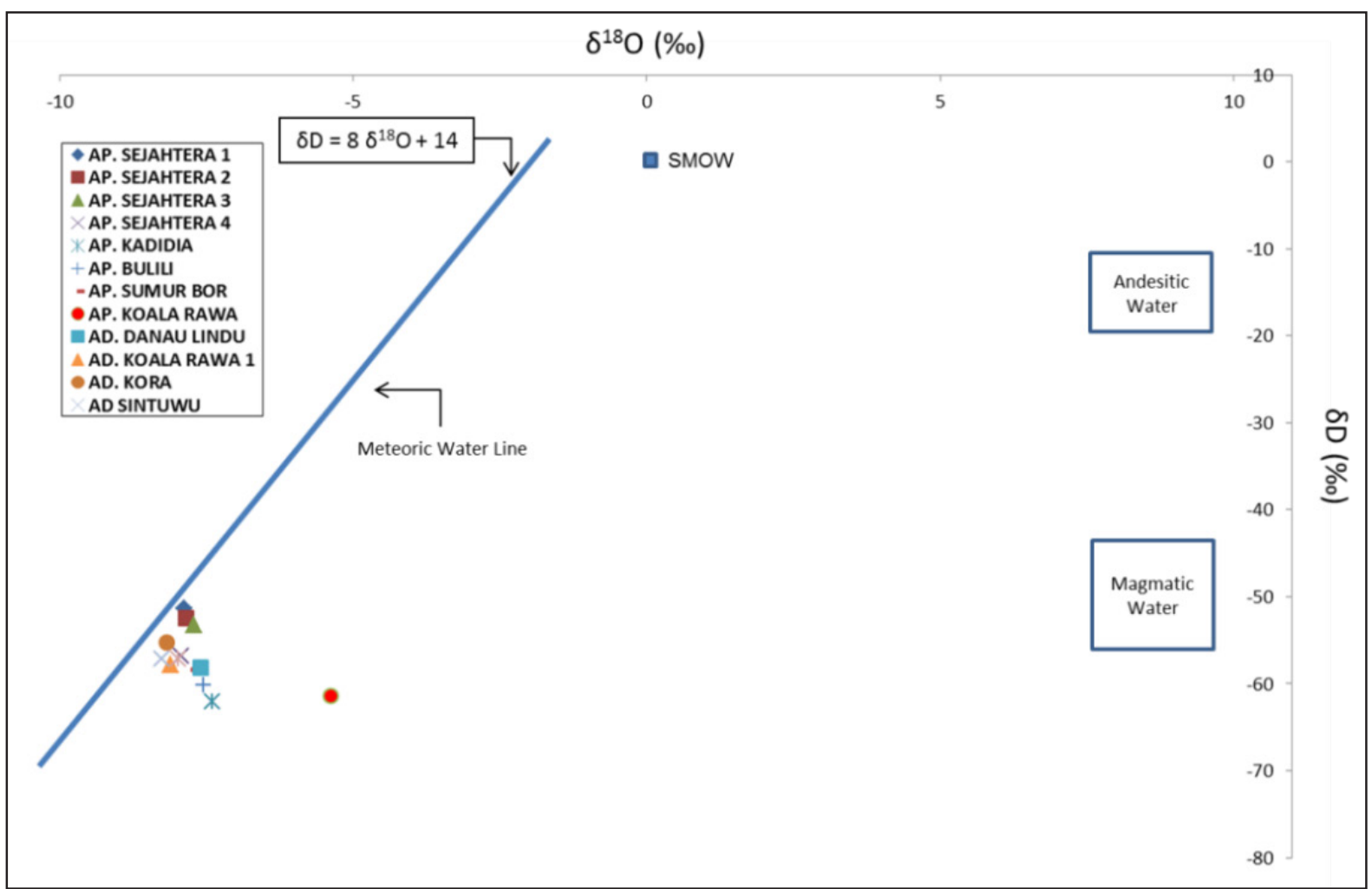

Gambar 7. Grafik isotop $\delta^{18} \mathrm{O}$ dan $\delta \mathrm{D}$ daerah panas bumi Kadidia

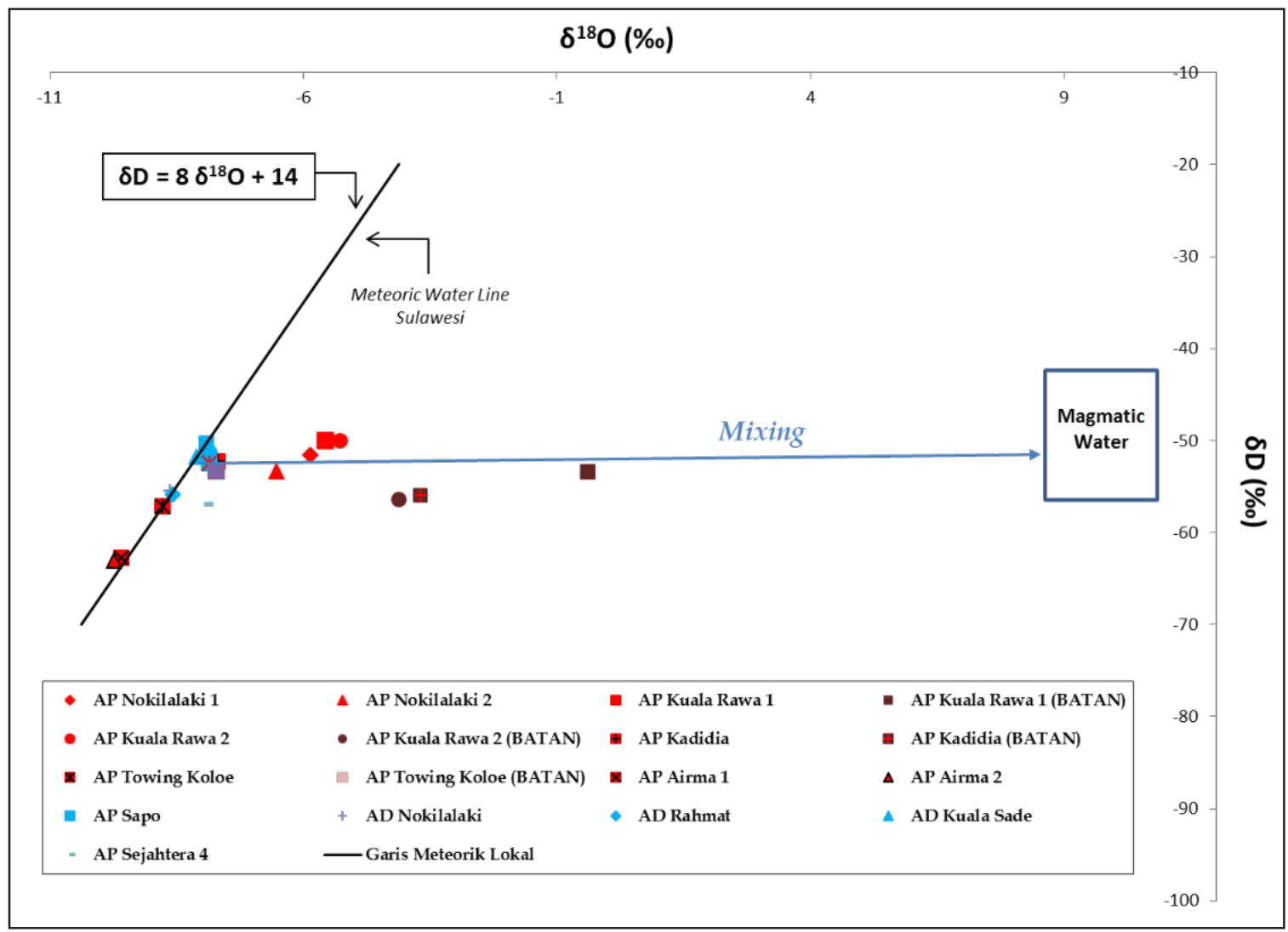

Gambar 8. Grafik isotop $\delta^{18} \mathrm{O}$ dan $\delta \mathrm{D}$ daerah panas bumi Kadidia Selatan 
Komposisi gas di daerah manifestasi Koala Rawa (Tabel 2) sangat didominasi oleh kandungan gas $\mathrm{N}_{2}, \mathrm{O}_{2}$, dan $\mathrm{CO}_{2}$ dibandingkan gas-gas lainnya yang relatif sangat kecil. Kandungan $\mathrm{N}_{2}$ dan $\mathrm{O}_{2}$ yang cukup tinggi menandakan bahwa ada pengaruh udara luar pada sampel gas yang diambil. Kandungan $\mathrm{CO}_{2}$ yang tinggi menandakan bahwa reaksi yang berlangsung di bawah permukaan akan menghasilkan kandungan $\mathrm{HCO}_{3}{ }^{-}$yang tinggi dalam larutan air panas. Indikasi gas-gas tersebut dicerminkan oleh komposisi kimiawi mata air panas di daerah Kadidia Selatan yang mengandung ion bikarbonat yang cukup tinggi. Hal ini memperlihatkan oleh adanya uap yang naik dari kedalaman sebagai air bawah permukaan yang bertemperatur tinggi dan mengalami tingkat proses pendinginan dikarenakan penurunan temperatur dengan gas $\mathrm{CO}_{2}$ yang tersisa di dalam uap yang naik melalui batuan membentuk ion bikarbonat.

Dari data analisis gas yang diperoleh, dilakukan plotting pada grafik Norman dan Moore (1999) untuk mengetahui asal-usul gas tersebut (gambar 9). Dari grafik tersebut terlihat bahwa gas-gas tersebut berasal dari fluida meteorik yaitu pengaruh udara luar cukup dominan, namun ada sedikit pengaruh dari fluida magmatik. Oleh karena itu, hasil analisis gas ini tidak bisa digunakan untuk memperkirakan temperatur reservoar dengan menggunakan geotermometer gas. Adanya pengaruh fluida magmatik juga sejalan dengan hasil analisis isotop, dimana pembentukan fluida panas bumi di daerah Kadidia Selatan ada pengaruh pencampuran dengan fluida magmatik.

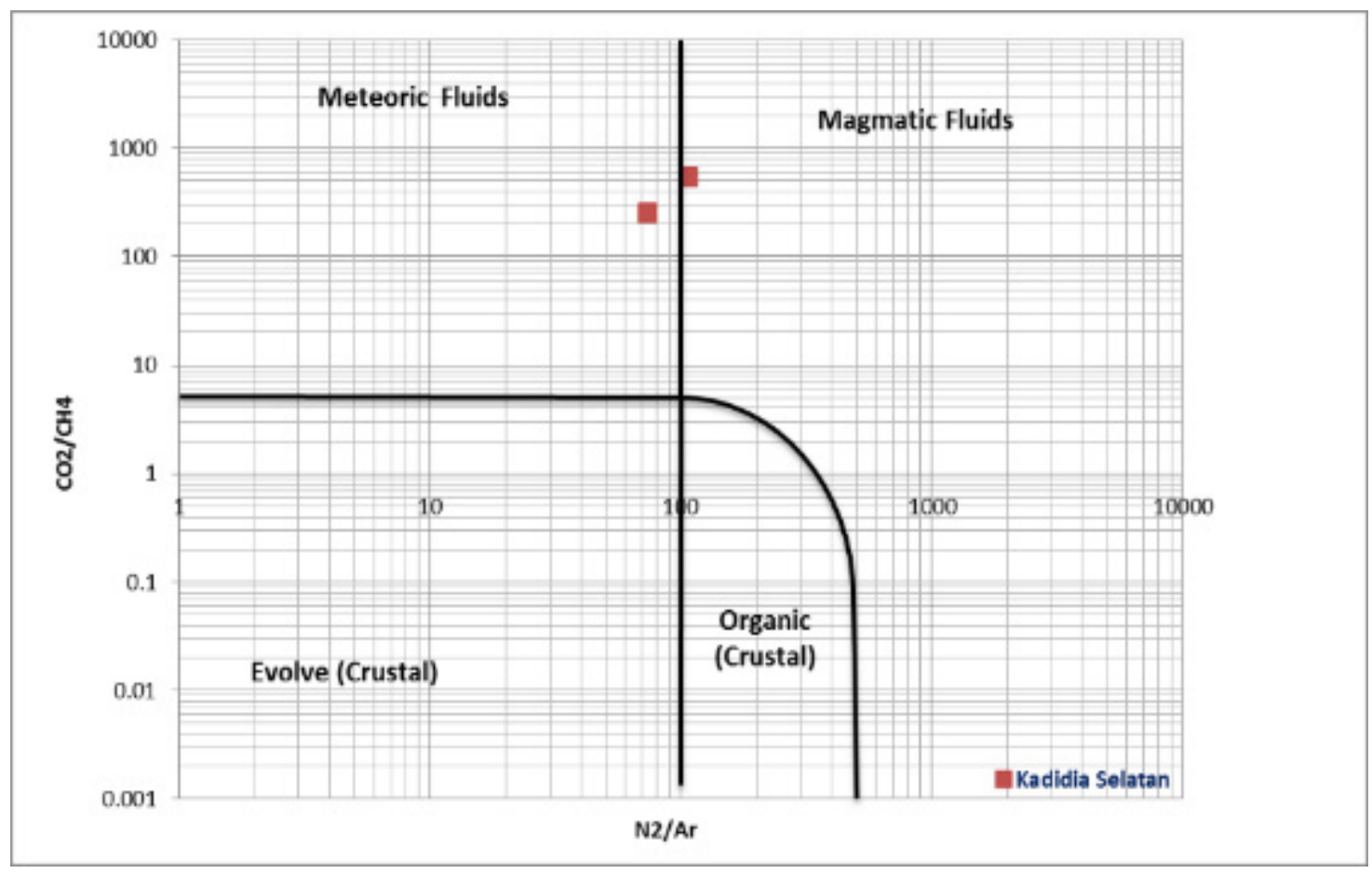

Gambar 9. Grafik asal-usul gas daerah Kadidia Selatan (Norman dan Moore, 1999)

Perkiraan temperatur bawah permukaan daerah Kadidia Selatan dengan menggunakan geotermometer $\mathrm{SiO}_{2}$ (conductive-cooling) rata-rata berkisar antara $190^{\circ} \mathrm{C}$ s.d $210^{\circ} \mathrm{C}$ dan termasuk ke dalam entalpi sedang. Perkiraan temperatur berdasarkan geotermometer Na-K didapatkan $200^{\circ} \mathrm{C}$ s.d $260^{\circ} \mathrm{C}$ (entalpi 


\section{MAKALAH ILMIAH}

tinggi), sedangkan dari geotermometer $\mathrm{Na}-\mathrm{K}-\mathrm{Ca}$ didapatkan temperatur sekitar $200^{\circ} \mathrm{C}$ (Tabel 4).

Dengan melihat karakteristik kimia air panas, terutama dari Koala Rawa dan Nokilalaki, seperti $\mathrm{pH}$ netral, suhu permukaan yang tinggi, terdapat sinter silika, bertipe klorida, dan berada di zona partial equilibrium, maka geotermometer $\mathrm{Na} / \mathrm{K}$ paling tepat digunakan.

Berdasarkan hasil plotting entalpi klorida menunjukkan temperatur parent fluid sebesar $240^{\circ} \mathrm{C}$ dengan konsentrasi klorida sebesar 305 ppm (Gambar 10), sehingga diperkirakan temperatur reservoar panas bumi Kadidia Selatan sebesar $240^{\circ} \mathrm{C}$.

Pada daerah panas bumi Kadidia yang diperkirakan memiliki reservoar yang berbeda, memiliki temperatur reservoar yang lebih kecil dari daerah panas bumi Kadidia Selatan. Berdasarkan geotermometer $\mathrm{Na}-\mathrm{K}$, temperatur reservoar daerah Kadidia sebesar $130^{\circ} \mathrm{C}$ s.d $140^{\circ} \mathrm{C}$.

Tabel 4. Hasil perhitungan geotermometer daerah Kadidia dan Kadidia Selatan

\begin{tabular}{|c|c|c|c|c|c|c|c|c|c|c|c|}
\hline \multirow{2}{*}{ Parameter } & \multicolumn{9}{|c|}{ KADIDIA } & \multicolumn{5}{c|}{ KADIDIA SELATAN } \\
\cline { 2 - 12 } & $\begin{array}{c}\text { AP } \\
\text { Sejahtera } \\
\mathbf{1}\end{array}$ & $\begin{array}{c}\mathbf{A P} \\
\text { Sejahtera } \\
\mathbf{2}\end{array}$ & $\begin{array}{c}\mathbf{A P} \\
\text { Sejahtera } \\
\mathbf{3}\end{array}$ & $\begin{array}{c}\mathbf{A P} \\
\text { Sejahtera } \\
\mathbf{4}\end{array}$ & $\begin{array}{c}\text { AP } \\
\text { Bulili }\end{array}$ & $\begin{array}{c}\text { AP } \\
\text { Kadidia }\end{array}$ & $\begin{array}{c}\text { AP } \\
\text { Nokilalaki } \\
\mathbf{1}\end{array}$ & $\begin{array}{c}\text { AP } \\
\text { Nokilalaki } \\
\mathbf{2}\end{array}$ & $\begin{array}{c}\text { AP Koala } \\
\text { Rawa 1 }\end{array}$ & $\begin{array}{c}\text { AP Koala } \\
\text { Rawa 2 }\end{array}$ & $\begin{array}{c}\text { AP } \\
\text { Towing } \\
\text { Koloe }\end{array}$ \\
\hline Temp & 51 & 62,8 & 57,8 & 57,4 & 40,4 & 81,6 & 80,5 & 90,4 & 96,6 & 98,8 & 40,2 \\
\hline $\mathbf{p H}$ & 6,97 & 8,41 & 7,83 & 7,75 & 6,82 & 8,32 & 8,32 & 7,9 & 9,41 & 7,91 & 7,1 \\
\hline $\mathbf{S i O 2}$ & 54,94 & 58,34 & 57,85 & 42,39 & 42,81 & 65,37 & 296,4 & 195,84 & 270,83 & 275,51 & 47,82 \\
\hline $\mathbf{N a}$ & 95,12 & 87,13 & 112,8 & 64,24 & 54,52 & 128,3 & 343,5 & 294,8 & 379,6 & 372,4 & 15,96 \\
\hline $\mathbf{K}$ & 2,57 & 2,12 & 2,30 & 2,78 & 2,59 & 2,80 & 37 & 44,9 & 30,77 & 33,21 & 2,3 \\
\hline $\mathbf{C a}$ & 7,86 & 0,31 & 5,83 & 1,83 & 9,49 & 2,19 & 12,3 & 20,3 & 8,6 & 15 & 10,05 \\
\hline T SiO2 (cc) & $\mathbf{1 0 6}$ & $\mathbf{1 0 9}$ & $\mathbf{1 0 9}$ & $\mathbf{9 4}$ & $\mathbf{9 5}$ & $\mathbf{1 1 5}$ & $\mathbf{2 0 9}$ & $\mathbf{1 7 9}$ & $\mathbf{2 0 2}$ & $\mathbf{2 0 3}$ & $\mathbf{1 0 0}$ \\
\hline TSiO2 (ac) & $\mathbf{1 0 7}$ & $\mathbf{1 0 9}$ & $\mathbf{1 0 9}$ & $\mathbf{9 6}$ & $\mathbf{9 7}$ & $\mathbf{1 1 4}$ & $\mathbf{1 9 1}$ & $\mathbf{1 6 7}$ & $\mathbf{1 8 6}$ & $\mathbf{1 8 7}$ & $\mathbf{1 0 1}$ \\
\hline T NaK (G) & $\mathbf{1 4 6}$ & $\mathbf{1 4 0}$ & $\mathbf{1 3 1}$ & $\mathbf{1 7 3}$ & $\mathbf{1 7 9}$ & $\mathbf{1 3 4}$ & $\mathbf{2 3 8}$ & $\mathbf{2 6 8}$ & $\mathbf{2 1 6}$ & $\mathbf{2 2 3}$ & $\mathbf{2 6 3}$ \\
\hline T NaK (F) & $\mathbf{1 2 6}$ & $\mathbf{1 2 0}$ & $\mathbf{1 1 0}$ & $\mathbf{1 5 5}$ & $\mathbf{1 6 1}$ & $\mathbf{1 1 4}$ & $\mathbf{2 2 4}$ & $\mathbf{2 5 6}$ & $\mathbf{2 0 0}$ & $\mathbf{2 0 8}$ & $\mathbf{2 5 1}$ \\
\hline T Na-K-Ca & $\mathbf{7 4}$ & $\mathbf{1 3 5}$ & $\mathbf{7 9}$ & $\mathbf{1 4 3}$ & $\mathbf{6 5}$ & $\mathbf{1 2 2}$ & $\mathbf{2 0 3}$ & $\mathbf{2 1 6}$ & $\mathbf{1 9 2}$ & $\mathbf{1 9 2}$ & $\mathbf{4 9}$ \\
\hline
\end{tabular}

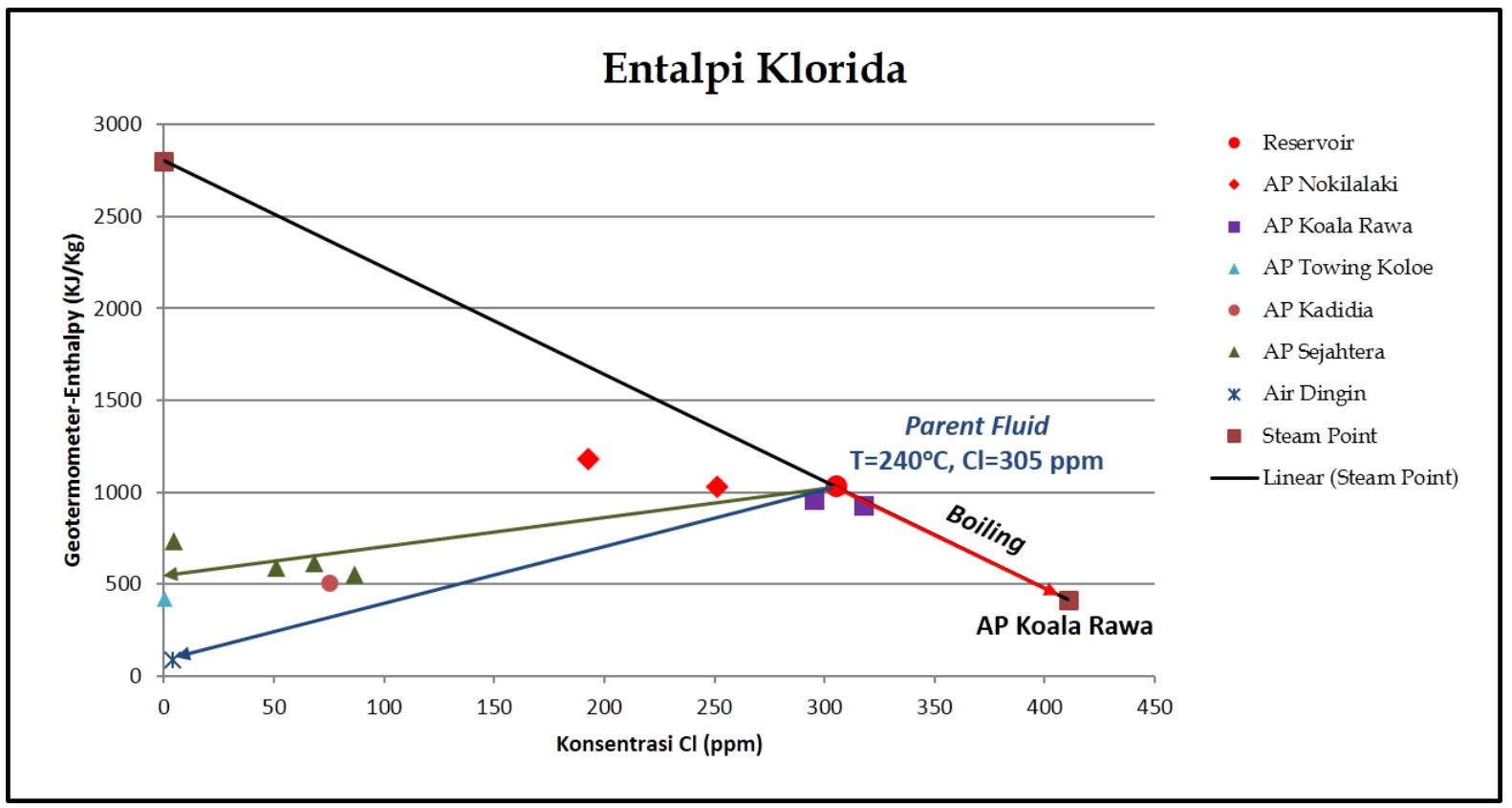

Gambar 10. Entalpi klorida daerah Kadidia dan Kadidia Selatan 


\section{Diskusi}

Berdasarkan data geokimia fluida dan rekonstruksi struktur geologi, diperkirakan daerah panas bumi Kadidia dan Kadidia Selatan memiliki reservoar yang berbeda. Fluida dari masing-masing daerah isotop $\delta^{18} \mathrm{O}$ dan $\delta \mathrm{D}$ menunjukkan bahwa isotop kedua daerah tersebut memiliki karakteristik yang berbeda. Daerah Kadidia Selatan memiliki komposisi isotop yang lebih berat dibandingkan komposisi isotop daerah Kadidia. Oleh karena itu, diperkirakan fluida reservoar dari kedua daerah tersebut berasal dari reservoar yang berbeda.

Data geologi menunjukkan sebaran litologi yang berbeda antara Kadidia dan Kadidia Selatan, sehingga dua daerah ini kemungkinan memiliki batuan reservoar yang berbeda. Selain itu konstruksi struktur geologi menguatkan bahwa daerah Kadidia dan Kadidia Selatan memiliki zona struktur yang berbeda pula meskipun berasal dari tegasan yang sama.

Komposisi gas juga menunjukkan adanya sedikit pengaruh fluida magmatik pada gas yang keluar pada tanah panas Koala Rawa. Hasil ini sejalan dengan data geologi yang memperkirakan adanya tubuh intrusi granit di kedalaman. tersebut menunjukkan karakteristik kimia yang berbeda, seperti silika, klorida, bikarbonat, sulfat, dan daya hantar listrik. Unsur-unsur konservatif seperti $\mathrm{Cl}$, B, dan $\mathrm{Li}$ memiliki rasio berbeda, begitu pula dengan

hasil

Fluida panas daerah Kadidia diperkirakan terbentuk akibat sirkulasi dalam/deep water circulation dengan batuan panas di kedalaman, sedangkan fluida panas daerah Kadidia Selatan diperkirakan selain terbentuk akibat sirkulasi dalam juga terdapat pengaruh aktivitas tektonik aktif. Sebagai gambaran pada tahun 2012 terjadi aktifitas kegempaan di Danau Lindu yang merupakan daerah terdekat dengan posisi manifestasi di Kadidia Selatan, sehingga energi yang terlepaskan lebih mudah tertangkap pada batuan intrusif (jenis granitik) pada sistem panas bumi Kadidia Selatan.

Temperatur reservoar daerah Kadidia Selatan diperkirakan sebesar $240^{\circ} \mathrm{C}$, sedangkan daerah Kadidia sebesar $140^{\circ} \mathrm{C}$. Perkiraan kedalaman reservoar belum dapat ditentukan karena belum ada data geofisika, namun menurut Tamanyu dan Sakaguchi (2003) (Gambar 11), diperkirakan reservoar Kadidia Selatan yang berhubungan dengan batuan intrusi dan aktivitas tektonik terletak lebih dangkal dibandingkan reservoar Kadidia. 


\section{MAKALAH ILMIAH}

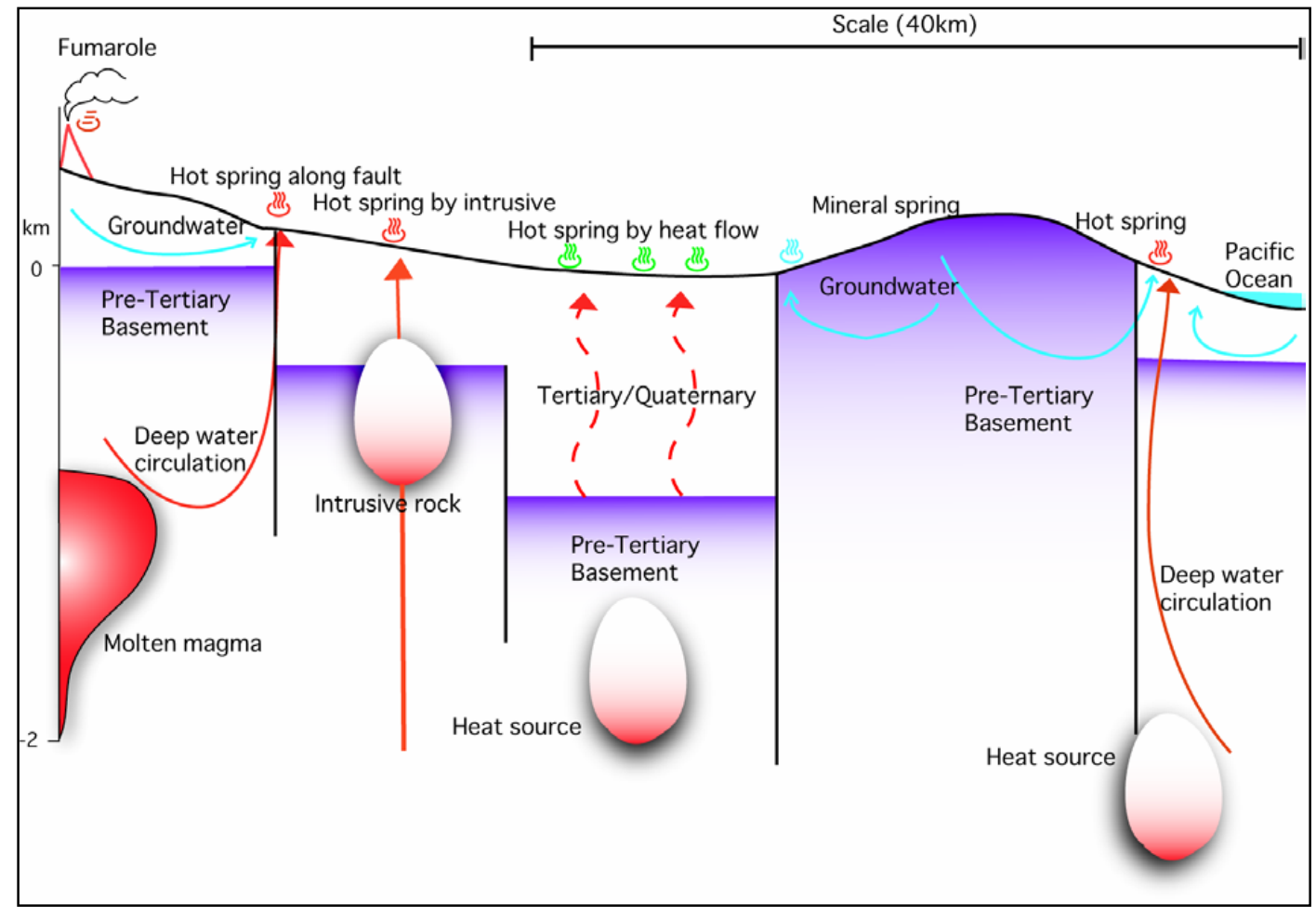

Gambar 11. Model konseptual sistem panas bumi nun-vulkanik

(Tamanyu dan Sakaguchi, 2003)

Pola aliran fluida ditunjukkan pada model geokimia daerah Kadidia dan Kadidia Selatan. Fluida panasbumi bertipe klorida (Cl) yang berasal dari reservoar akan mengalir ke atas sebagai upflow di daerah Kadidia Selatan. Di bagian lain di daerah penelitian, air $\mathrm{Cl}$ bercampur dengan air $\mathrm{HCO}_{3}$, yang terbentuk di dekat permukaan karena proses steam heating, yaitu kondensasi uap air panas dengan air tanah. Sedangkan sisa uap air dapat muncul di permukaan sebagai tanah beruap (Gambar 12).

Karakteristik alterasi batuan di sekitar air panas Kadidia Selatan menunjukkan terdapat mineral-mineral yang terbentuk pada temperatur tinggi seperti epidot, ilit, dan kaolinit. Sinter silika terbentuk di sekitar manifestasi Koala Rawa yang bertemperatur mendidih, sedangkan sinter travertin terbentuk semakin ke selatan kearah manifestasi air hangat. Sinter silika dan travertin juga hadir bersamaan pada air panas Nokilalaki yang bertemperatur $80,5^{\circ} \mathrm{C}$ yang berlokasi di antara pemunculan sinter silika dan travertin. Pemunculan epidot, sinter silika dan travertin pada manifestasi Kadidia Selatan menunjukkan bahwa telah terjadi evolusi fluida pada sistem panas bumi tersebut. Evolusi fluida yang terjadi berupa pendinginan (cooling) atau pemanasan (heating) belum dapat ditentukan karena memerlukan studi lebih lanjut, seperti inklusi fluida.

Reservoar daerah panas bumi ini diperkirakan hanya berupa spot-spot kecil di sekitar area manifestasi yang merupakan zona lemah yang memiliki permeabilitas tinggi yang dapat menyebabkan pemunculan manifestasi di permukaan, sehingga daerah prospek panas bumi untuk daerah-daerah ini tidak terlalu 


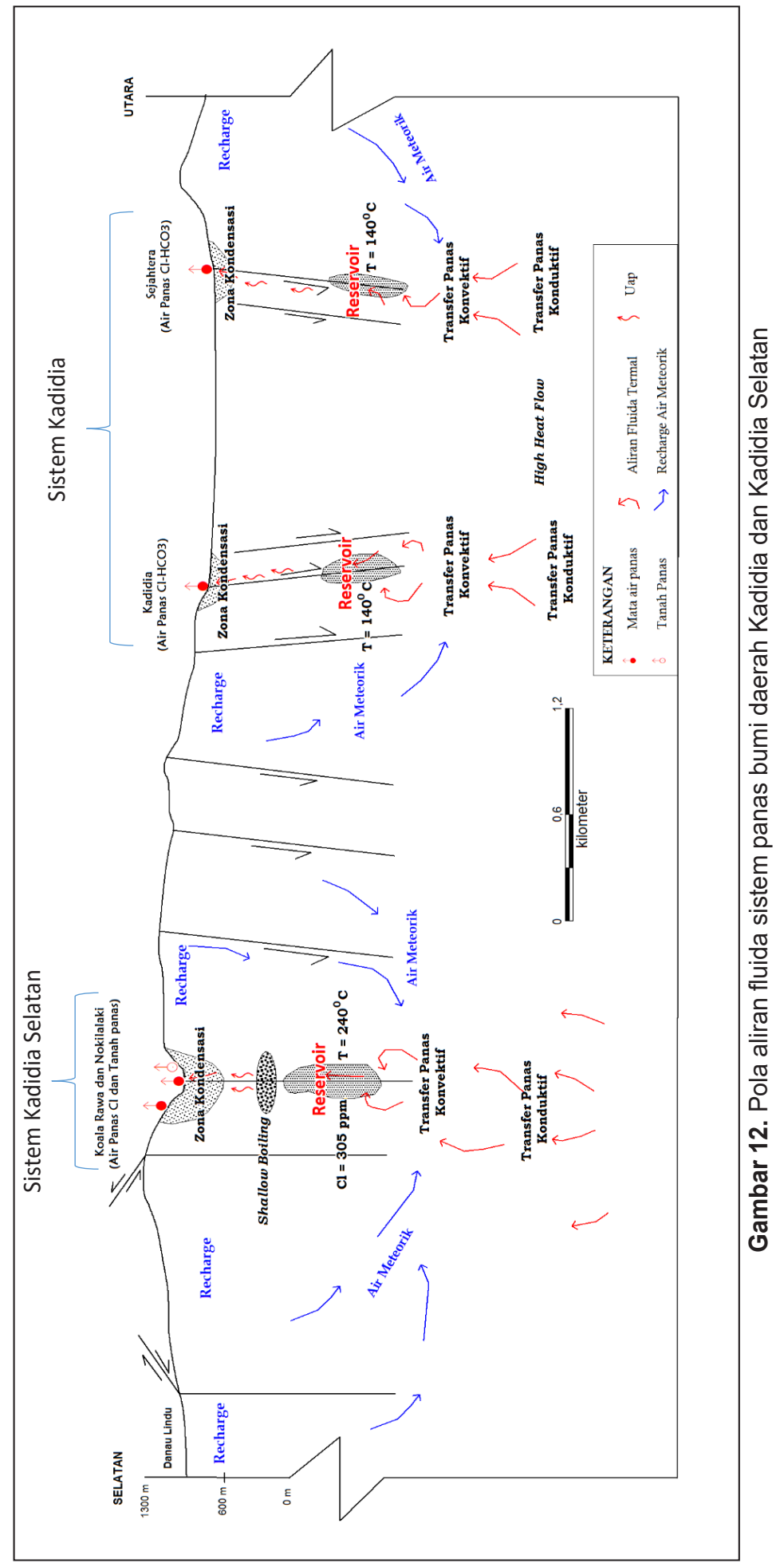




\section{MAKALAH ILMIAH}

\section{KESIMPULAN}

Studi geokimia air panasbumi dan geologi menunjukkan, bahwa air panas yang muncul di daerah panas bumi Kadidia dan Kadidia Selatan diperkirakan memiliki reservoar yang berbeda, dengan temperatur reservoar daerah Kadidia Selatan lebih tinggi dibandingkan daerah Kadidia. Temperatur reservoar daerah Kadidia Selatan diperkirakan sebesar $240^{\circ} \mathrm{C}$, sedangkan daerah kadidia sebesar $140^{\circ} \mathrm{C}$ dengan kedalaman reservoar daerah Kadidia terletak lebih dalam dibandingkan daerah Kadidia Selatan.

Fluida panas bumi di daerah Kadidia Selatan diperkirakan berasal dari pengaruh intrusi granit yang terpanaskan kembali oleh aktivitas tektonisme. Sedangkan fluida panas bumi daerah Kadidia diperkirakan akibat sirkulasi air dalam yang keluar ke permukaan sebagai air panas melalui horst dari sistem depresi Kadidia.

\section{UCAPAN TERIMA KASIH}

Penulis ucapkan terima kasih kepada rekan-rekan Kelompok Penyelidikan Panas Bumi yang telah meluangkan waktu untuk berdiskusi, tim editor yang telah memberikan koreksi dan saran dalam penyusunan makalah ini serta dewan redaksi atas kesempatan yang telah diberikan sehingga makalah ini dapat diterbitkan.

\section{DAFTAR PUSTAKA}

Anonim, 2012. Survey Terpadu Geologi dan Geokimia Daerah Panas Bumi Kadidia, Kabupaten Sigi, Sulawesi Tengah, Badan Geologi, Bandung (Unpublished report).

Anonim, 2014. Survey Terpadu Geologi dan Geokimia Daerah Panas

Bumi Kadidia Selatan,

Kabupaten Sigi, Sulawesi

Tengah, Badan Geologi,

Bandung (Unpublished report).

Fournier, R.O., 1981. Application of Water Geochemistry Geothermal Exploration and Reservoar Engineering, Geothermal

System: Principles and Case Histories. John Willey \& Sons. New York.

Giggenbach, W.F., 1988. Geothermal Solute Equilibria Deviation of $\mathrm{Na}-\mathrm{K}-\mathrm{Mg}$ - Ca Geo- Indicators. Geochemica Acta 52. pp. 2749 -2765 .

Hamilton W., 1979. Tectonic of Indonesia Region,

Geol.Surv.Prof.Papers,U.S.Govt .Print Off.,Washington.

Herdianita, N.R., dan Julinawati, T., 2007. Hidrogeokimia Air Panasbumi Daerah Cidanau dan Sekitarnya, Anyer, Provinsi Banten Berdasarkan Manifestasi Permukaannya. Jurnal Geoaplika, Vol 2, No 3, hal. $105-119$.

Hutchinson,C.S.,1989. Geological Evolution of South-East Asia, Oxford Mono. Geol. Geoph., 13, Clarendon Press, Oxford

Mahon K. and Ellis, A.J., 1977. Chemistry and Geothermal System. Academic Press Inc. Orlando

Marini, L., 2001. Geochemical Techniques for the Exploration and Exploitation of Geothermal Energy, Dipartimento per lo Studio del Territorio e delle sue Risorse, Università Degli Studi di Genova, Italy.

Nicholson, K., 1993. Geothermal Fluids; Chemistry and Exploration Techniques, Springer-Verlag, Berlin. 


\section{MAKALAH ILMIAH}

Norman, D.I., and Moore, J.N., 1999. Methane and Excess N2 and Ar in Geothermal Fluid Inclusions. Twenty-Fourth Workshop on Geothermal Reservoar Engineering, Stanford
University, pp. 196-202.

Tamanyu, S. and Sakaguchi, K., 2003. Conceptual Model For NonVolcanic Resources., Geothermal
Geothermal

European Conference.

$\begin{array}{ll}\text { Diterima } & : 11 \text { Juni } 2015 \\ \text { Direvisi } & : 27 \text { Juli } 2015 \\ \text { Disetujui } & : 6 \text { Agustus } 2015\end{array}$

